\title{
Genetic variability in three species of Gymnotus Linnaeus, 1758 (Gymnotiformes: Gymnotidae) from Caracu stream of the upper Paraná River basin, Brazil
}

\author{
Judy Ruiz Rezende ${ }^{1}$, Erasmo Renesto² and Cláudio Henrique Zawadzki ${ }^{3}$
}

\begin{abstract}
The genetic variability of three Gymnotus species from the Caracu stream, a small tributary of the left margin of Paraná River (Brazilian upper Paraná River floodplain), was estimated with data of 17 putative allozyme loci, which were obtained by using corn starch gel electrophoresis of 10 enzymatic systems: Aspartate aminotransferase (E. C. 2.6.1.1), Alcohol dehydrogenase (E. C. 1.1.1.1), Esterase (E. C. 3.1.1.1), Glucose dehydrogenase (E. C. 1.1.1.118), Glycerol-3-phosphate dehydrogenase (E. C. 1.1.1.8), Isocitrate dehydrogenase (E. C. 1.1.1.42), L-Lactate dehydrogenase (E. C. 1.1.1.27), Malate dehydrogenase (E. C. 1.1.1.37), Superoxide dismutase (E. C. 1.15.1.1) and Sorbitol dehydrogenase (E. C. 1.1.1.14). The genetic diversity was estimated as $\mathrm{He}=$ 0.3458 for $G$. pantanal, $H e=0.2481$ for $G$. inaequilabiatus, and $H e=0.3152$ for $G$. sylvius. The most divergent species were $G$. sylvius and G. pantanal $(\mathrm{D}=0.117)$, and the most similar were $G$. inaequilabiatus and $G$. pantanal $(\mathrm{D}=0.051)$. The data indicates that the observed genetic variability was very low and the expected variability estimated for these three species is very high, and the genetic differences among them are small. The data suggest that the process of speciation which produced these three species is recent.
\end{abstract}

A variabilidade genética de três espécies de Gymnotus do riacho Caracu, um pequeno afluente da margem esquerda do rio Paraná (planície de inundação do alto rio Paraná) foi estimada com base em 17 loci aloenzimáticos, os quais foram obtidos utilizando eletroforese em gel de amido de milho em 10 sistemas enzimáticos: Aspartato aminotransferase (E. C. 2.6.1.1), Álcool desidrogenase (E. C. 1.1.1.1), Esterase (E. C. 3.1.1.1), Glicose desidrogenase (E. C. 1.1.1.118), Glicerol-3-fosfato desidrogenase (E. C. 1.1.1.8), Isocitrato desidrogenase (E. C. 1.1.1.42), L-Lactato desidrogenase (E. C. 1.1.1.27), Malato desidrogenase (E. C. 1.1.1.37), Superóxido dismutase (E. C. 1.15.1.1) e Sorbitol desidrogenase (E. C. 1.1.1.14). A diversidade genética foi estimada em $H e=0.3458$ para G. pantanal, $\mathrm{He}=0,2481$ para $G$. inaequilabiatus, e $H e=0,3152$ para G. sylvius. As espécies mais divergentes foram G. sylvius e G.pantanal ( $\mathrm{D}=0,117)$, e as mais semelhantes foram $G$. inaequilabiatus e G. pantanal $(\mathrm{D}=0,051)$. Os dados mostram que a variabilidade genética observada é muito baixa, mas a esperada é muito alta e que as diferenças genéticas entre elas são pequenas. Os dados sugerem que o processo de especiação que originou as três espécies é recente.

Key words: Polymorphism, Genetic distance, Allozyme, Heterozygosity.

\section{Introduction}

The order Gymnotiformes comprises six families: Sternopygidae, Apteronotidae, Rhamphichthyidae, Hypopomidae, Gymnotidae and Electrophoridae (MagoLeccia, 1994). The genus Gymnotus Linnaeus, 1758 includes 32 species, and possesses a larger geographical distribution, when compared to all the other Gymnotiformes. This distribution extends from Salado River in the Pampas of
Argentina $\left(36^{\circ} \mathrm{S}\right)$ to San Nicolas River of the southeast of Chiapas in Mexico $\left(18^{\circ} \mathrm{N}\right)$. It is present in continental waters of all South American and Central American countries, except from Chile and Belize (Albert, 2001; Albert et al., 2005).

The largest Gymnotus diversity is found in the Amazonian basin, and most of them inhabit flooded areas (Albert \& Crampton, 2001). However, little information on the diversity of species, distribution and populational structure of this genus in other Neotropical basins is available (Fernandes-

1PPrograma de Pós-Graduação em Ecologia de Ambientes Aquáticos Continentais, Universidade Estadual de Maringá. Av. Colombo, 5790,
87020-900 Maringá, PR, Brazil. judyruizrezende@hotmail.com
2Departamento de Biologia Celular e Genética, Universidade Estadual de Maringá. Av. Colombo, 5790, 87020-900 Maringá, PR, Brazil.
erenesto@hotmail.com
${ }^{3}$ Departamento de Biologia, Universidade Estadual de Maringá. Av. Colombo, 5790, 87020-900 Maringá, PR, Brazil. chzawadzki@hotmail.com 
Matioli et al., 2000).

The Gymnotus species are aggressive nocturnal predators of fishes and other small aquatic animals, and many of them are territorial. The males of at least two Gymnotus species build nests of foam and/or aquatic vegetation and guard them (Albert \& Crampton, 2003). Males of G. carapo, for instance, either dig depressions in the substratum or make nests at the roots of aquatic macrophytes (Crampton \& Hopkins, 2005).

The Gymnotus species have been object of ecological studies (Barbieri \& Barbieri, 1984; Cognato \& Fialho, 2006; Ferreira \& Casatti, 2006), cytogenetic analysis (Foresti et al., 1984; Murofushi \& Yosida, 1984; Fernandes-Matioli et al., 1997, 1998a, 1998b; Margarido et al., 2007), phylogenetic approaches (Albert, 2001; Fernandes-Matioli \& AlmeidaToledo, 2001; Albert et al., 2005) and systematic studies (Albert \& Miller, 1995; Campos-da-Paz, 1996, 2000; Albert et al., 1999; Fernandes-Matioli et al., 2000; Crampton \& Albert, 2004; Fernandes et al., 2005). However, genetic variability estimates of the Gymnotus species have never been made. Estimates of genetic variability in natural populations are important in order to evaluate their evolutionary potentialities as well as to establish species conservation policies.

The upper Paraná River floodplain has 230 km of length, up to $20 \mathrm{~km}$ of width and is formed by several ponds, streams, Baía River and lower stretches of Paraná, Ivaí, Ivinheíma, Amambaí, and Iguatemi rivers (Agostinho \& Zalewski, 1996). According to Agostinho \& Júlio Jr. (1999), the genus Gymnotus is present in ponds and in some channels, rivers and streams that flow to Paraná River, being rarely found in the main valley of this river. In these rivers and streams it is possible to find three species of Gymnotus: G. inaequilabiatus (Valenciennes, 1839), G. sylvius Albert et al., 1999 and G. pantanal Fernandes et al., 2005.

The populations of these three species are found in syntopy; they inhabit rooted grasses and floating macrophytes in small creeks and the banks of larger black water rivers patches of floating macrophytes along channel and lake margins areas (Fernandes et al., 2005). In the Caracu stream, which runs into Paraná River near Porto Rico County (PR), these three species are in syntopy.

The aim of this work was to estimate the genetic variability of three Gymnotus species occurring in the Caracu stream by using the isozyme electrophoresis technique. We also aimed at evaluating their interspecific genetic differences.

\section{Material and Methods}

The specimens analyzed were collected from December 2005 to March 2006 along the Caracu stream (Fig. 1). The Caracu stream is a small tributary of Paraná River eastern side, located in Porto Rico County, Paraná State, Brazil. It is classified as a second-order river, according to the classification of Jeffries \& Mills (1990). This small tributary has $5.2 \mathrm{~km}$ of length and its margins are degraded, except from a few forest stretches (Pavanelli \& Caramaschi, 2003).

Fifty five specimens of $G$. inaequilabiatus, 40 of $G$. pantanal and 16 of G. sylvius were collected. The 111 specimens captured were deposited in the ichthyological collection of Nupelia (Núcleo de Pesquisas em Limnologia, Ictiologia e Aquicultura) of Universidade Estadual de Maringá. Vouchers are NUP 3213 for G. inaequilatiatus, NUP 4184 for G. pantanal, and NUP 5962 for G. sylvius. This study was approved by the animal ethics committee of our institution and met all requirements under Brazilian environmental laws. Sampling was carried out under permission of the Brazilian environmental agency (Instituto Brasileiro do Meio Ambiente e dos Recursos Naturais Renováveis - IBAMA), protocol number 137/2006.

The collected tissues were homogenized with plastic sticks in $1.5 \mathrm{~mL}$ micro centrifuge tubes containing $100 \mu \mathrm{L}$ of Tris/0.02MHCl buffer, $\mathrm{pH}$ 7.5. Carbon tetrachloride (CCl4) was added to the homogenized liver samples due to the large amounts of fat present in the tissues (Pasteur et al., 1988). The homogenized samples were centrifuged at $45.114 \mathrm{x}$ g for $30 \mathrm{~min}$ at temperatures between $1^{\circ} \mathrm{C}$ and $5^{\circ} \mathrm{C}$ and the supernatants submitted to horizontal electrophoresis in 15\% corn starch gel (Val et al., 1981).

Ten enzymatic systems were evaluated (Table 1). Enzyme nomenclature followed the proposals of Murphy et al. (1996). Electrophoreses conditions were according to the following authors: Boyer et al. (1963) for AAT, ADH, EST, GDH, SOD; Shaw \& Prasad (1970) for G3PDH, IDH, LDH, MDH, and SORB.

Standard histochemical staining procedures were used to visualize specific enzymes (Aebersold et al., 1987). The genetic interpretation of the gels was based on the quaternary structure of the enzymes (Ward et al., 1992). The data was analyzed with POPGENE software, version 1.31 (Yeh et al., 1999). The genetic variability was estimated by using Nei's unbiased heterozygosity ( $\mathrm{He}$ ) or gene diversity (Nei, 1978).

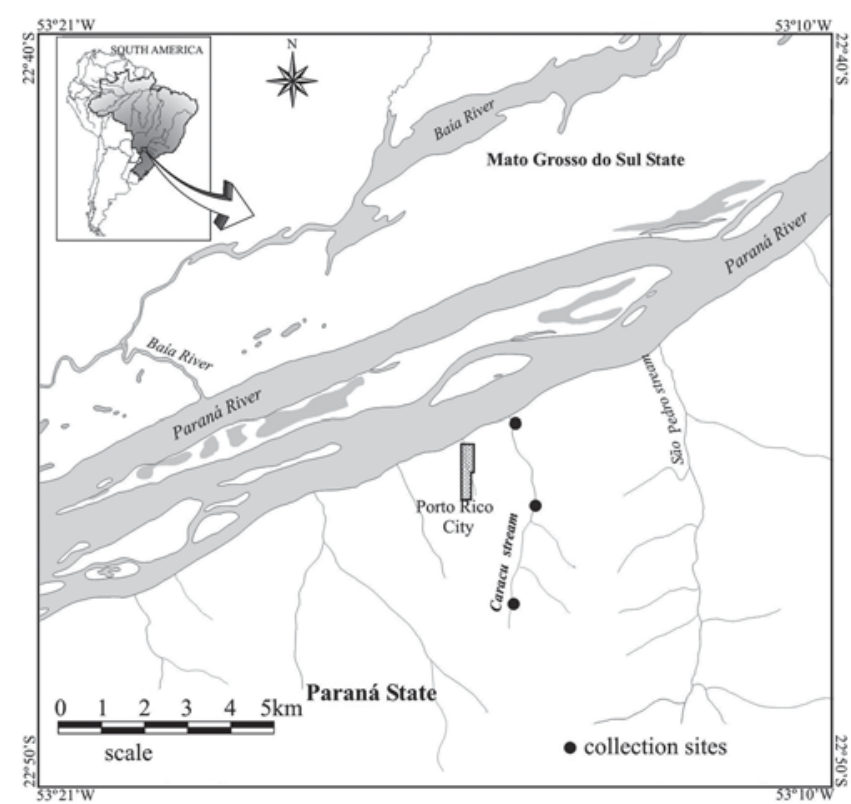

Fig. 1. Localization of Caracu stream where the Gymnotus specimens were collected. 
Table 1. Electrophoretic conditions for 10 enzymatic systems assayed for Gymnotus inaequilabiatus, G. sylvius and G. pantanal from Caracu stream, Paraná State, Brazil.

\begin{tabular}{lllll}
\hline \multicolumn{1}{c}{ Enzyme } & \multicolumn{1}{c}{ Tissue } & \multicolumn{1}{c}{ Buffer } & \multicolumn{1}{c}{ Time } & \multicolumn{1}{c}{ References } \\
\hline AAT, EST, ADH, GDH, SOD & Liver, Kidney & Tris/borate/EDTA 0.045/0.025/0.001M, pH 8.6 & 7 hours & Boyer et al. (1963) \\
G3PDH, LDH, SORB & Liver, Kidney & Tris/citrate 0.009/0.003M, pH 7.0 & 14 hours & Shaw \& Prasad (1970) \\
IDH, MDH & Liver, Muscle, Gill & Tris/citrate 0.009/0.003M, pH 7.0 & 14 hours & Shaw \& Prasad (1970) \\
\hline
\end{tabular}

The observed $(\mathrm{Ho})$ and expected $(\mathrm{He})$ heterozygosities for each putative locus and the overall loci means were also calculated. Genotypic frequencies were tested for HardyWeinberg equilibrium, by using the chi squared $\left(\chi^{2}\right)$ test. The Genetic Identity and the genetic distance were calculated according to Nei (1972). The comparison between the heterozygosities of these three species was made through a test for paired data (Nei, 1987).

\section{Results}

In this work 10 enzymatic systems were analyzed in 111 specimens of Gymnotus, 55 Gymnotus inaequilabiatus, 40 Gymnotus pantanal and 16 Gymnotus sylvius. The allele frequencies are summarized in Table 2 and the estimates of genetic variability of these species in Table 3 . Table 4 shows the values of the $\chi^{2}$ test for homogeneity of the allele frequencies among the three species, and Table 5 presents the values of genetic identity and genetic distance of Nei (1972).

In most of the enzymatic systems it was possible to detect more than one locus except for GDH, G3PDH and SORB, which presented just one. The Malate dehydrogenase (MDH) enzymatic system presented three loci; one of them $(M d h-B)$ is monomorphic.

All the loci presented more than one allele in at least one population, and the locus Sorb-1 presented four alleles for the population of $G$. inaequilabiatus. No diagnostic locus was found to differentiate these three species in the enzymatic systems analyzed. However, some alleles with low frequency and exclusive for each population were detected: $L d h-1(c)$ e Sorb-1(d) for G. inaequilabiatus, Aat-1(b), Aat-2(b) e Est1(c) for G. pantanal and G3pd-1(a) for G. sylvius. None of the polymorphic loci is in Hardy-Weinberg equilibrium.

The observed heterozygosity $(\mathrm{Ho})$ measures revealed that there were heterozygotes in only three of the seventeen loci in G. pantanal and G. inaequilabiatus, while no heterozygote was detected in G. sylvius, probably due to the low number of analyzed individuals. On the other hand, the number of polymorphic loci was 13 (76.47\%), 15 (88.24\%) and 14 (82.35\%) for G. inaequilabiatus, G. pantanal and G. sylvius, respectively.

The estimates of genetic variability showed that G. sylvius presented the smallest heterozygosity observed and the smallest average number of alleles per locus $(\mathrm{Na}=1.88)$. Gymnotus pantanal presented the largest expected heterozygosity $(\mathrm{He})$, the largest proportion of polymorphic loci $(88.24 \%)$, and also the largest average number of alleles per locus $(\mathrm{Na}=2.18)$, while $G$. inaequilabiatus presented intermediate values of genetic variability. The expected heterozygosity for $G$. pantanal is significantly greater than the expected for $G$. inaequilabiatus ( $\mathrm{t}=2.88$; 16 d.f.; $\mathrm{p}<0.05$ ). On the other hand, the expected heterozygosity for $G$. pantanal is not significantly greater than the expected for $G$. sylvius ( $\mathrm{t}=0.505$; 16 d.f.; $\mathrm{p}>0.05$ ), and the expected for $G$. sylvius is not significantly greater than the expected for $G$. inaequilabiatus $(\mathrm{t}=1.35 ; 16$ d.f.; $\mathrm{p}>0.05)$. The expected heterozygosity measures are much higher than the

Table 2. Allele frequencies for three Gymnotus species from Caracu stream, Paraná State, Brazil. Bold type indicates exclusive alleles for each species.

\begin{tabular}{|c|c|c|c|c|}
\hline Locus & Allele & G. inaequilabiatus & G. pantanal & G. sylvius \\
\hline Aat-1 & $\begin{array}{l}a \\
b\end{array}$ & 1.0000 & $\begin{array}{l}0.9615 \\
\mathbf{0 . 0 3 8 5}\end{array}$ & 1.0000 \\
\hline Aat-2 & $\begin{array}{l}a \\
b\end{array}$ & 1.0000 & $\begin{array}{l}0.9474 \\
\mathbf{0 . 0 5 2 6}\end{array}$ & 1.0000 \\
\hline Est-1 & $\begin{array}{l}a \\
b \\
c\end{array}$ & $\begin{array}{l}0.7182 \\
0.2818\end{array}$ & $\begin{array}{l}0.5526 \\
0.1184 \\
\mathbf{0 . 3 2 8 9}\end{array}$ & $\begin{array}{l}0.6667 \\
0.3333\end{array}$ \\
\hline Est-2 & $\begin{array}{l}a \\
b\end{array}$ & $\begin{array}{l}0.7308 \\
0.2692\end{array}$ & $\begin{array}{l}0.8250 \\
0.1750\end{array}$ & $\begin{array}{l}0.8333 \\
0.1667\end{array}$ \\
\hline Adh-1 & $\begin{array}{l}a \\
b \\
c\end{array}$ & $\begin{array}{l}0.6389 \\
0.3333 \\
0.0278\end{array}$ & $\begin{array}{l}0.3750 \\
0.1667 \\
0.4583\end{array}$ & $\begin{array}{l}0.3333 \\
0.6667\end{array}$ \\
\hline$G d h-1$ & $\begin{array}{l}a \\
b \\
c\end{array}$ & $\begin{array}{l}0.0182 \\
0.9636 \\
0.0182\end{array}$ & $\begin{array}{l}0.0250 \\
0.9500 \\
0.0250\end{array}$ & $\begin{array}{c}0.16667 \\
0.8333\end{array}$ \\
\hline G3pd-1 & $\begin{array}{l}a \\
b\end{array}$ & 1.0000 & 1.0000 & $\begin{array}{l}\mathbf{0 . 5 0 0 0} \\
0.5000\end{array}$ \\
\hline$I d h-1$ & $\begin{array}{l}a \\
b\end{array}$ & $\begin{array}{l}0.0952 \\
0.9048\end{array}$ & $\begin{array}{l}0.2381 \\
0.7619\end{array}$ & $\begin{array}{l}0.3333 \\
0.6667\end{array}$ \\
\hline$I d h-2$ & $\begin{array}{l}a \\
b\end{array}$ & $\begin{array}{l}0.0217 \\
0.9783\end{array}$ & $\begin{array}{l}0.4103 \\
0.5897\end{array}$ & 1.0000 \\
\hline$L d h-A$ & $\begin{array}{l}a \\
b \\
c\end{array}$ & $\begin{array}{l}0.0400 \\
0.9400 \\
\mathbf{0 . 0 2 0 0}\end{array}$ & $\begin{array}{l}0.3243 \\
0.6757\end{array}$ & $\begin{array}{l}0.2000 \\
0.8000\end{array}$ \\
\hline$L d h-B$ & $\begin{array}{l}a \\
b\end{array}$ & $\begin{array}{l}0.0816 \\
0.9184\end{array}$ & $\begin{array}{l}0.0385 \\
0.9615\end{array}$ & $\begin{array}{l}0.2500 \\
0.7500\end{array}$ \\
\hline$M d h-A$ & $\begin{array}{l}a \\
b \\
c\end{array}$ & $\begin{array}{l}0.5455 \\
0.4545\end{array}$ & $\begin{array}{l}0.4615 \\
0.3590 \\
0.1795\end{array}$ & $\begin{array}{l}0.1667 \\
0.6667 \\
0.1667\end{array}$ \\
\hline$M d h-B$ & $a$ & 1.0000 & 1.0000 & 1.0000 \\
\hline$M d h-C$ & $\begin{array}{l}a \\
b\end{array}$ & $\begin{array}{l}0.3491 \\
0.6509\end{array}$ & $\begin{array}{l}0.4359 \\
0.5641\end{array}$ & $\begin{array}{l}0.6000 \\
0.4000\end{array}$ \\
\hline Sorb-1 & $\begin{array}{l}a \\
b \\
c \\
d\end{array}$ & $\begin{array}{l}0.5435 \\
0.2826 \\
0.1304 \\
\mathbf{0 . 0 4 3 5}\end{array}$ & $\begin{array}{l}0.3333 \\
0.1905 \\
0.4762\end{array}$ & $\begin{array}{l}0.4000 \\
0.6000\end{array}$ \\
\hline Sod-1 & $\begin{array}{l}a \\
b\end{array}$ & $\begin{array}{l}0.7812 \\
0.2188\end{array}$ & $\begin{array}{l}0.6786 \\
0.3214\end{array}$ & 1.0000 \\
\hline Sod-2 & $\begin{array}{l}a \\
b \\
\end{array}$ & $\begin{array}{l}0.6735 \\
0.3265 \\
\end{array}$ & $\begin{array}{l}0.5714 \\
0.4286 \\
\end{array}$ & $\begin{array}{l}0.2000 \\
0.8000\end{array}$ \\
\hline
\end{tabular}


Table 3. Genetic variability estimates for each locus of the Gymnotus species from Caracu stream, Paraná State, Brazil. $H_{o}=$ observed heterozygosity; $H_{e}=$ unbiased expected heterozygosity; $\mathrm{SD}=$ standard deviation; $\mathrm{N}=$ number of specimens; $\mathrm{Na}=$ mean number of alleles per locus; $\mathrm{Ne}=$ effective number of alleles per locus; $\mathrm{P}=$ proportion of polymorphic loci.

\begin{tabular}{lcccccc}
\hline & \multicolumn{2}{c}{ G. inaequilabiatus } & \multicolumn{2}{c}{ G. pantanal } & \multicolumn{2}{c}{ G. sylvius } \\
\cline { 2 - 7 } Locus & $H_{o}$ & $H_{e}$ & $H_{o}$ & $H_{e}$ & $H_{o}$ & $H_{e}$ \\
\hline Aat -1 & 0.0000 & 0.0000 & 0.0000 & 0.0754 & 0.0000 & 0.0000 \\
Aat -2 & 0.0000 & 0.0000 & 0.0000 & 0.1011 & 0.0000 & 0.0000 \\
Est-1 & 0.0182 & 0.4085 & 0.0263 & 0.5800 & 0.0000 & 0.4848 \\
Est-2 & 0.0000 & 0.3973 & 0.0500 & 0.2924 & 0.0000 & 0.3030 \\
Adh-1 & 0.0000 & 0.4867 & 0.0000 & 0.6348 & 0.0000 & 0.4848 \\
Gdh-1 & 0.0000 & 0.0714 & 0.0000 & 0.0975 & 0.0000 & 0.3030 \\
G3pd-1 & 0.0000 & 0.0000 & 0.0000 & 0.0000 & 0.0000 & 0.5455 \\
Idh-1 & 0.0000 & 0.1744 & 0.0000 & 0.3717 & 0.0000 & 0.4848 \\
Idh-2 & 0.0000 & 0.0430 & 0.0000 & 0.4902 & 0.0000 & 0.0000 \\
Ldh-A & 0.0000 & 0.1156 & 0.0000 & 0.4443 & 0.0000 & 0.3556 \\
Ldh-B & 0.0000 & 0.1515 & 0.0000 & 0.0754 & 0.0000 & 0.4286 \\
Mdh-A & 0.0000 & 0.5004 & 0.0000 & 0.6340 & 0.0000 & 0.5455 \\
Mdh-B & 0.0000 & 0.0000 & 0.0000 & 0.0000 & 0.0000 & 0.0000 \\
Mdh-C & 0.0943 & 0.4588 & 0.2051 & 0.4982 & 0.0000 & 0.5333 \\
Sorb-1 & 0.0435 & 0.6193 & 0.0000 & 0.6411 & 0.0000 & 0.5333 \\
Sod-1 & 0.0000 & 0.3472 & 0.0000 & 0.4442 & 0.0000 & 0.0000 \\
Sod -2 & 0.0000 & 0.4444 & 0.0000 & 0.4987 & 0.0000 & 0.3556 \\
mean & 0.0092 & 0.2481 & 0.0166 & 0.3458 & 0.0000 & 0.3152 \\
SD & 0.0246 & 0.2166 & 0.0504 & 0.2379 & 0.0000 & 0.2237 \\
N & \multicolumn{3}{c}{55} & \multicolumn{2}{c}{40} & \multicolumn{2}{c}{16} \\
Na \pm SD & $2.05 \pm 0.80$ & $2.18 \pm 0.64$ & $1.88 \pm 0.48$ \\
Ne \pm SD & $1.44 \pm 0.46$ & $1.71 \pm 0.61$ & $1.60 \pm 0.37$ \\
P & $76.47 \%$ & $88.24 \%$ & $82.35 \%$ \\
\hline
\end{tabular}

heterozygosity values obtained for the three species. This fact reveals homozygote excess. The homogeneity test (Table 4) showed that the allele frequencies in the three species differed statistically in ten out of the seventeen loci studied.

\section{Discussion}

The band pattern obtained for the 10 analyzed systems and the loci number detected in Gymnotus are very similar to those obtained for other species of neotropical fish (Zawadzki et al., 2001). The presence of exclusive alleles indicates that these three species are in process of genetic divergence.

The estimates of expected average heterozygosity for $G$. inaequilabiatus (0.248), G. pantanal (0.346) and G. sylvius (0.315) are high when compared to the values described by Ward et al. (1994) for 59 species of freshwater fish (0.046), and to the values detected by Machado \& Renesto (2007) for nine species of fish from the floodplain of the upper Paraná River (0 to 0.147 ).

The fact that no locus is in the Hardy-Weinberg equilibrium and the presence of a homozygote excess may be due to inbreeding, once these species are of sedentary habits. Homozygote excess have also been found in the Hypostomus species from the upper Paraná and Paraguay River basins, which also have sedentary habits (Zawadzki et al., 2002, 2004, 2005; Paiva et al., 2005; Renesto et al., 2007)

The genetic distance and genetic identity values among
Table 4. Chi-square test for homogeneity of allele frequencies for G. inaequilabiatus, G. pantanal and G. sylvius from Caracu stream, Paraná State, Brazil. Bold type indicates the loci which were statistically different. $\chi^{2}=$ chi-square value; $\mathrm{DF}=$ degree of freedom.

\begin{tabular}{lccc}
\hline \multicolumn{1}{c}{ Locus } & $\chi^{2}$ & DF & Probability \\
\hline Aat -1 & 2.659713 & 2 & 0.264515 \\
Aat -2 & 6.447368 & $\underline{2}$ & $\mathbf{0 . 0 3 9 8 0 8}$ \\
Est -1 & 48.136494 & $\underline{4}$ & $\mathbf{0 . 0 0 0 0 0 0}$ \\
Est -2 & 2.551745 & 2 & 0.279187 \\
Adh -1 & 44.904085 & $\underline{4}$ & $\mathbf{0 . 0 0 0 0 0 0}$ \\
Gdh -1 & 8.684470 & 4 & 0.069489 \\
G3pd -1 & 49.820000 & $\underline{2}$ & $\mathbf{0 . 0 0 0 0 0 0}$ \\
Idh-1 & 7.230631 & 2 & 0.026908 \\
Idh- -2 & 43.211523 & $\underline{2}$ & $\mathbf{0 . 0 0 0 0 0 0}$ \\
Ldh- $A$ & 26.460840 & $\underline{4}$ & $\mathbf{0 . 0 0 0 0 2 6}$ \\
Ldh- $B$ & 4.539571 & 2 & 0.103334 \\
Mdh- $A$ & 25.588794 & $\underline{4}$ & $\mathbf{0 . 0 0 0 0 3 8}$ \\
Mdh- $B$ & 0.000000 & 0 & 1.000000 \\
Mdh - C & 3.232424 & 2 & 0.198650 \\
Sorb -1 & 22.288405 & $\underline{6}$ & $\mathbf{0 . 0 0 1 0 7 3}$ \\
Sod -1 & 20.238961 & $\underline{2}$ & $\mathbf{0 . 0 0 0 0 4 0}$ \\
Sod -2 & 9.079258 & $\underline{2}$ & $\mathbf{0 . 0 1 0 6 7 7}$ \\
\hline
\end{tabular}

Table 5. Genetic identity (above diagonal) and genetic distance (below diagonal) of Nei (1972), for three Gymnotus species from Caracu stream, Paraná State, Brazil.

\begin{tabular}{lccc}
\hline \multicolumn{1}{c}{ Species } & 1 & 2 & 3 \\
\hline $1-$ G. inaequilabiatus & - & 0.950 & 0.908 \\
2 - G. pantanal & 0.051 & - & 0.889 \\
$3-G$. sylvius & 0.097 & 0.117 & - \\
\hline
\end{tabular}

the three species of Gymnotus showed that the populations with larger genetic divergence were G. sylvius and $G$. inaequilabiatus $(\mathrm{D}=0.117)$, and the genetically closest populations were G. inaequilabiatus and G. pantanal (D = 0.051). Nei's genetic distance, $D$, is claimed to estimate the average number of electrophoretically detectable substitutions per locus and, given certain assumptions, to be linearly proportional to evolutionary time (Thorpe \& Solé-Cava, 1994).

The genetic (I) identity, which varies from 0 to 1 , represents the proportion of the gene products that are not electrophoretically detectable (Thorpe, 1982). The genetic identity of Nei (1972) varies from 0.80 and 1.00 between two populations of the same species and from 0.02 to 0.98 between two species of the same genus. Thorpe concluded that the critical level for I values distinguishing between species and genera appears to be around 0.35 . If allopatric populations of uncertain status usually have genetic identities below 0.85 it is unlikely that they should be considered conspecific, while nominate species with I values above 0.85 should be considered doubtful if there is no other evidence of their specific status. The values of genetic identity (Table 5) among the species analyzed in this work are inside the limits of the same species populations. However, these species possess morphological and chromosomal differences and a combination of different microsatellite patterns (Fernandes, 2000) that allow us to affirm that they are distinct from each 
other. Besides, the three species are syntopic and no intermediate types are found among them. It reveals the absence of crossing and reproductive isolation among them. Considering the distance values and the genetic identity obtained in this work we can estimate that the speciation event leading to the origin of these species is very recent.

We consider further studies using molecular markers to be needed for confirming or refuting the low genetic variability estimated for these species.

\section{Acknowledgements}

The authors thank NUPELIA (Núcleo de Pesquisas em Limnologia, Ictiologia e Aquicultura) of the Universidade Estadual de Maringá for helping at the fish collection, Weferson Junio da Graça for identifying the species, Corn Products Brazil, for providing penetrose 50, Jaime L. L. Pereira for drawing the map and CAPES (Coordenação de Aperfeiçoamento do Ensino Superior) for financial support.

\section{Literature Cited}

Aebersold, P. B., G. A. Winans, D. J. Tell, G. B. Milner \& M. Utter. 1987. Manual for starch gel electrophoresis: a method for the detection of genetic variation. NOAA Technical Report NMFS, 61: 1-17.

Agostinho, A. A. \& H. F. Júlio Jr. 1999. Peixes da bacia do alto rio Paraná. Pp. 374-400. In: Lowe-McConnell, R. H. (Ed.). Estudos ecológicos de comunidades de peixes tropicais. São Paulo, Editora da Universidade de São Paulo, 534p.

Agostinho, A. A. \& M. A. Zalewski. 1996. Planície alagável do alto rio Paraná: importância e preservação. Maringá, Eduem, 100p.

Albert, J. S. 2001. Species diversity and phylogenetic systematics of American knifefishes (Gymnotiformes, Teleostei). Miscellaneous Publications of the Museum of Zoology, University of Michigan, 190: 1-127.

Albert, J. S. \& W. G. R. Crampton. 2001. Five new species of Gymnotus (Gymnotiformes, Teleostei) from an Upper Amazonian floodplain, with descriptions of electric organ discharges and ecology. Ichthyological Exploration of Freshwaters, 12(3): 241-266.

Albert, J. S. \& W. G. Crampton. 2003. Seven new species of the Neotropical electric fish Gymnotus (Teleostei, Gymnotiformes) with a redescription of $G$. carapo (Linnaeus). Zootaxa, 287: 1-54.

Albert, J. S., W. G. Crampton, D. H. Thorsen \& N. R. Lovejoy. 2005. Phylogenetic systematics and historical biogeography of the Neotropical electric fish Gymnotus (Teleostei: Gymnotidae). Systematic and Biodiversity, 2: 375-417.

Alber, J. S., F. M. Fernandes-Matioli \& L. F. Almeida-Toledo. 1999. New species of Gymnotus (Gymnotiformes, Teleostei) from southeastern Brazil: towards the deconstruction of Gymnotus carapo. Copeia, 1999(2): 410-421.

Albert, J. S. \& R. R. Miller. 1995. Gymnotus maculosus, a new species of electric fish (Chordata: Teleostei: Gymnotoidei) from Middle America, with a key to species of Gymnotus. Proceedings of the Biological Society Washington, 108: 662-678.

Barbieri, G. \& M. C. Barbieri. 1984. Note on nutritional dynamics of Gymnotus carapo (L) from the Lobo Reservoir, São Paulo State, Brazil. Journal of Fish Biology, 24: 351-355.
Boyer, S. H., D. C. Fainer \& M. A. Naughton. 1963. Myoglobin: inherited structural variation in man. Science, 140: 1228-1231.

Campos-da-Paz, R. 1996. Redescription of the central American electric fish Gymnotus cylindricus (Ostariophysi: Gymnotiformes: Gymnotidae), with comments on character ambiguity within the Ostariophysan clade. Journal of Zoology, 240: 371-382.

Campos-da-Paz, R. 2000. Taxonomic status of Rhamphichthys cingulatus Brind and a more precise assignment of the typelocality of Gymnotus coatesi LaMonte (Ostariophysi: Gymnotiformes). Copeia, 2000(4): 1114-1117.

Cognato, D. P. \& C. B. Fialho. 2006. Reproductive biology of a population of Gymnotus aff. carapo (Teleostei: Gymnotidae) from southern Brazil. Neotropical Ichthyology, 4(3): 339-348.

Crampton, W. G. R. \& J. S. Albert. 2004. Redescription of Gymnotus coatesi (Gymnotiformes, Gymnotidae): A rare species of electric fish from the lowland Amazon Basin, with descriptions of osteology, electric signals, and ecology. Copeia, 2004(3): 525-533.

Crampton, W. G. R. \& C. D. Hopkins. 2005. Nesting and Paternal Care in the Weakly Electric Fish Gymnotus (Gymnotiformes: Gymnotidae) with Descriptions of Larval and Adult Electric Organ Discharges of Two Species. Copeia, 2005(1): 48-60.

Fernandes-Matioli, F. M. C., J. S. Albert, M. F. Z. Daniel-Silva, C. Lopes, W. G. R. Crampton \& L. F. Almeida-Toledo. 2005. A new Gymnotus (Teleostei: Gymnotiformes: Gymnotidae) from the Pantanal Matogrossense of Brazil and adjacent drainages: continued documentation of a cryptic fauna. Zootaxa, 933: 1-14.

Fernandes-Matioli, F. M. C. \& L. F. Almeida-Toledo. 2001. A molecular phylogenetic analysis in Gymnotus species (Pisces: Gymnotiformes) with inferences on chromosome evolution. Caryologia, 54: 23-30.

Fernandes-Matioli, F. M. C., L. F. Almeida-Toledo \& A. S. Toledo. 1997. Extensive nucleolus organizer region polymorphism in Gymnotus carapo (Gymnotoidei, Gymnotidae). Cytogenetics and Cell Genetics, 78(3-4): 236-239.

Fernandes-Matioli, F. M. C., L. F. Almeida-Toledo \& A. S. Toledo. 1998b. Natural triploidy in the Neotropical species Gymnotus carapo (Pisces: Gymnotiformes). Caryologia, 51: 319-322.

Fernandes-Matioli, F. M. C., M. C. N. Marchetto \& L. F. AlmeidaToledo. 1998a. High intraspecific karyological conservation in four species of Gymnotus (Pisces: Gymnotiformes) from Southeastern Brazilian basins. Caryologia, 51: 221-234.

Fernandes-Matioli, F. M. C., S. R. Matioli \& L. F. Almeida-Toledo. 2000. Species diversity and geographic distribution of Gymnotus (Pisces: Gymnotiformes) by nuclear (GGAC)(n) microsatellite analysis. Genetics and Molecular Biology, 23(4): 803-807.

Ferreira, C. P. \& L. Casatti. 2006. Habitat structure and stream fishes in a pasture basin, São Paulo, Brazil. Revista Brasileira de Zoologia, 23(3): 642-651.

Foresti, F., L. F. D. Toledo \& S. A. Toledo.1984. Chromosome studies in Gymnotus carapo and Gymnotus sp. (Pisces, Gymnotidae). Caryologia, 37: 141-146.

Jeffries, M. \& D. Mills. 1990. Freshwater Ecology Principles and Applications. Chichester, John Wiley \& Sons, 285p.

Machado, M. D. P. L. \& E. Renesto. 2007. Reproductive strategies and genetic variability in tropical freshwater fish. Genetics and Molecular Biology, 30(3): 690-697.

Mago-Leccia, F. 1994. Electric fishes of the continental water of America: classification and catalogue of the electric fishes of the order Gymnotiformes (Teleostei: Ostariophysi), with descriptions of new genera and species. Caracas, Fundacion para el desarrolho de las Ciencias Fisicas, Matematicas y Naturales, 29, 206p. 
Margarido, V. P., E. Bellafronte \& O. Moreira-Filho. 2007. Cytogenetic analysis of three sympatric Gymnotus (Gymnotiformes, Gymnotidae) species verifies invasive species in the Upper Paraná River basin, Brazil. Journal of Fish Biology, 70(Suppl. B): 155-164.

Murofushi, M. \& T. H. Yosida. 1984. Cytogenetical Studies On Fishes .VIII. XX-Y Sex-Chromosome Mechanism Newly Found In The Snake Eel, Muraenichthys gymnotus (Anguilliform, Pieces). Proceedings of Japan Academy B - Physical and Biological Sciences, 60(2): 21-23.

Murphy, R. W., J. W. Sites Jr., D. G. Buth \& C. H. Haufler. 1996. Proteins: Isozyme electrophoresis. Pp. 51-120. In: Hillis, D. M., C. Moritz \& B. K. Mable (Eds.). Molecular Systematics. Sunderland, Sinnauer Associates Inc., 655p.

Nei, M. 1972. Genetic distance between populations. American Naturalist, 106: 283-291.

Nei, M. 1978. Estimation of average of heterozygosity and genetic distance from small number of individuals. Genetics, 89(3): 583-590.

Nei, M. 1987. Molecular Evolutionary Genetics. New York, Columbia University Press, 512p.

Paiva, S., E. Renesto \& C. H. Zawadzki. 2005. Genetic variability of Hypostomus (Teleostei: Loricariidae) from the Ribeirão Maringá, a stream of the upper Rio Paraná basin, Brazil. Genetics and Molecular Biology, 28(3): 370-375.

Pasteur, N., G. Pasteur, F. Bonhomme, J. Catalan \& J. BrittonDavidian. 1988. Practical Isozyme Genetics. Chichester, Ellis Horwood, 215p.

Pavanelli, C. S. \& E. P. Caramaschi. 2003. Temporal and spatial distribution of the ichthyofauna in two streams of the Upper Rio Paraná Basin. Brazilian Archives of Biology and Technology, 46(2): 271-280.

Renesto, E., C. H. Zawadzki \& S. Paiva. 2007. Allozyme differentiation and relationships within Hypostomus Lacépède, 1803 (Osteichthyes: Loricariidae) from the upper Paraguay River basin, Brazil. Biochemical Systematics and Ecology, 35(12): 869-876.

Shaw, C. R. \& R. Prasad. 1970. Starch gel electrophoresis of enzymes: a compilation of recipes. Biochemical Genetics, 4(2): 297-320.

Thorpe, J. P. 1982. The molecular clock hypothesis: biochemical evolution, genetic differentiation and systematics. Annual Review in Ecology and Systematics, 13: 130-168.

Thorpe, J. P. \& A. M. Solé-Cava. 1994. The use of allozyme electrophoresis in invertebrate Systematics. Zoologica Scripta, 23(1): 3-18.

Val, A. L., A. R. Schwantes, M. L. B. Schwantes \& P. H. de Luca. 1981. Amido hidrolisado de milho como suporte eletroforético. Ciência e Cultura, 33: 737-741.

Ward, R. D., D. O. F. Skibinski \& M. Woodward. 1992. Protein heterozygosity, protein structure and taxonomic differentiation. Evolutionary Biology, 26: 73-59.

Ward, R. D., M. Woodwark \& D. O. F. H. Skibinski. 1994. A comparison of genetic diversity levels in marine, freshwater, and anadromous fishes. Journal of Fish Biology, 44(2): 213232.

Yeh, F. C., R. Yang \& T. Boyle. 1999. Population genetic analysis of co-dominant and dominant markers and quantitative traits. Belgian Journal of Botany, 129: 157.

Zawadzki, C. H., M. F. P. S. Machado \& E. Renesto. 2001. Differential expression for tissue-specific isozymes in three species of Hypostomus Lacépède, 1803 (Teleostei: Loricariidae). Biochemical Systematics and Ecology, 29(9): 911-922.
Zawadzki, C. H., E. Renesto, S. Paiva \& M. C. S. Lara-Kamei. 2004. Allozyme differentiation of four populations of Hypostomus (Teleostei:Loricariidae) from Ribeirão Keller, a stream in the upper Rio Parana basin, Brazil. Genetica, 121(3): 251-257.

Zawadzki, C. H., E. Renesto, R. E. Reis, M. O. Moura \& R. P. Mateus. 2005. Allozyme relationships in hypostomines (Teleostei: Loricariidae) from the Itaipu Reservoir, Upper Rio Parana basin, Brazil. Genetica, 123(3): 271-283.

Zawadzki, C. H., C. Weber, C. S. Pavanelli \& E. Renesto. 2002. Morphological and biochemical comparison of two allopatric populations of Hypostomus margaritifer (Regan, 1907) (Osteichthyes, Loricariidae) from the upper Paraná River basin, Brazil. Acta Scientiarum, Biological Sciences, 24: 499-505.

Accepted September 23, 2009 Published December 18, 2009 